\title{
Tropical yam (Dioscorea spp.) performance in western Puerto Rico'
}

\author{
P. R. Hepperly ${ }^{2}$ and Fr. Vázquez ${ }^{3}$
}

\begin{abstract}
Eighteen yam (Dioseorea spp.) cultivars from five species were evaluated for yield and severity of mosaic, anthracnose, and black leafspot (Curvularia spp.). Plantings were established at Mayagüez and Isabela, Puerto Rico, in the 1985-86 and 1986-87 growing seasons. Severe mosaic was found on D. trifida (Mina), which was the lowest producing cultivar both seasons. Five cultivars of $D$. esculenta (Kombi, Seti, Doli, Muni, and Beti) showed moderately severe mosaic symptoms in 1985-86, and black leafspot symptoms in 1986-87. Among these cultivars, Doli produced the highest tuber yields, $21,000 \mathrm{~kg} / \mathrm{ha}$ ( 9.4 tons/acre). Among D. alata cultivars, differences in anthracnose were related to genotype, location, and season. Leon Globe and Forastero were the most susceptible and lowest yielding cultivars. Gunung produced the highest yield, a maximum of about $40,000 \mathrm{~kg} / \mathrm{ha}$ ( 17.9 tons/acre). It was least affected by anthracnose, with less than $15 \%$ defoliation in November. Tuber yields in $D$. alata cultivars were highly associated with anthracnose severity ratings $(r=$ $\left.-0.81^{* *}\right)$. Both seasons more anthracnose was found in Isabela than in Mayagüez. Anthracnose was more severe in 1986-87 than 1985-86.
\end{abstract}

\section{RESUMEN}

Comportamiento del ñame (Dioscorea spp.)

Se evaluaron 18 cultivares de cinco especies de ñame (Dioscorea spp.) por su rendimiento y resistencia a mosaico, candelilla y la mancha negra en el campo durante 2 años consecutivos en Mayagüez e Isabela, Puerto Rico. La cultivar Mina de la especie $D$. trifida mostró síntomas severos de mosaico por lo cual arrojó una baja producción. Se evaluaron cinco variedades de ñame de papa, D. esculenta; todos mostraron síntomas de mosaico y ataques por la mancha negra de la hoja causada por Curvularia spp. La cultivar Doli sobresalió por su alta producción. En $D$. alata hubo gran variación en la severidad de la candelilla (antracnosis) causada por Colletotrichum gloeosporioides Penz. En los dos años hubo brotes de la candelilla más severos en Isabela que en Mayagüez. Leon Globe y Forastero fueron las cultivares más susceptibles a la candelilla. Gemelos fue severamente atacado por candelilla en Isabela en 1985-86 y moderadamente en 1986-87. Esta misma variedad resistió la candelilla en Mayagüez en 1986-87. Estas variaciones en reacción sugieren la existencia de distintas razas patológicas de Colletotrichum gloeosporioides en ñames en Puerto Rico o un gran efecto del lugar en la reacción de atracnosis.

${ }^{1}$ Manuscript submitted to Editorial Board 7 September 1988.

${ }^{2}$ Research Plant Pathologist .

${ }^{3}$ Horticulturalist, Tropical Agriculture Research Station, Box 70 Mayagüez, Puerto Rico 00709-0070. 


\section{INTRODUCTION}

Yams are an important food in the humid and subhumid tropics, where they serve as a valuable source of carbohydrates. Yams are well liked by Puerto Rican consumers, who pay premium prices for them. Guinea Blanco (Dioscorea rotundata) and Florido (D. alata) are the most commonly planted varieties. Yams are the most important locally produced tuber crop with a value of about $\$ 6$ million exceeding the local value of taniers and sweet potatoes.

Despite this production, Puerto Rico imports a large portion of the yams it consumes. Besides the excellent local market, there is great potential for exporting local yam production. Caribbean immigrants are a significant untapped export market in the United States and Europe.

Yam production has shifted from the production of Florido yams, which are susceptible to anthracnose, to Guinea Blanco, which is not affected by this malady. Despite the devastating effects of yam anthracnose, many consumers still prefer Florido yams, which demand higher prices based on their scarcity (5). Whereas Florido yams are susceptible to anthracnose, they are more resistant to nematodes and storage decay than Guinea Blanco. Control of yam anthracnose would increase the potential of D. alata in Puerto Rico and elsewhere in the Caribbean.

Given the importance of yams, work to introduce and evaluate $D$. alata cultivars is needed. Replacements for Florido with greater anthracnose resistance should be particularly emphasized. Anthracnose shows pathogenic variability in many crops $(1,6)$; therefore, identification of stable local resistance to anthracnose will need analysis of several seasons and locations.

Historically, Puerto Rico has hosted notable scientific work on yams. Martin and co-workers $(2,3,4)$ extensively collected and evaluated yam germplasm. Mignucci and co-workers (5) evaluated the major disease constraints to yam in Puerto Rico. The present studies encompass two years of yam evaluations in western Puerto Rico. The work complements findings of previous investigators and emphasizes alternative yams with local commercial potential.

\section{MATERIALS AND METHODS}

Experiments were conducted at the Isabela and Mayagüez facilities of the Tropical Agriculture Research Station, USDA-ARS, Mayagüez. At Isabela, the soil was an Oxisol (Tropepetic Haplorthox), and at Mayagüez a Ultisol (Dystropeptic Tropudults). Soils at both sites tend to be acid (less than $\mathrm{pH}$ 6). The Isabela soil was a sandy loam and at Mayagüez a heavy clay. The Isabela and Mayagüez sites ordinarily have subhumid and humid climates $(1,675 \mathrm{~mm}$ and $2,158 \mathrm{~mm}$, respectively, rainfall per annum). Both sites are coastal lowlands. 
Eighteen yam cultivars were evaluated (table 1). They were planted in 3-row plots with 1-m row centers and 7-m row lengths. Plantings were established with $125 \mathrm{~g}$ seed pieces. Tuber pieces were planted at the top 0.5 -m banks, at a density of 2 pieces per $\mathrm{m}$, giving a population of approximately 15,000 plants per ha (6,024 plants/acre). Vines were trellised to a height of $2 \mathrm{~m}$ and plots were irrigated and fertilized to maintain vigorous growth. Fertilizer 15-5-10 was applied at $500 \mathrm{~kg} / \mathrm{ha}$ in each of two applications. Applications were made at two weeks after planting and 2 months thereafter.

A randomized complete block design was employed with 3 replications per cultivar. Plantings were established from February 15 to April 15. No pesticides were applied in any of the trials.

From June to November, visual ratings of disease symptoms were recorded at a monthly interval. For mosaic, a 0 to 5 scale was used, with zero indicating no mosaic visible and 5 maximum mosaic severity. Anthracnose scores were based on estimated foliar area covered with necrotic lesions. Curvularia leafspot readings were based on the foliar area

TABLE 1.-Tuber yields of 18 tropical yam (Dioscorea spp.) cultivars at Isabela and Mayagüez, Puerto Rico, during the 1985-86 and 1986-87 growing seasons

\begin{tabular}{|c|c|c|c|c|}
\hline \multirow[b]{3}{*}{ Species and cultivar } & \multicolumn{4}{|c|}{ Tuber yield $(1,000 \mathrm{X} \mathrm{kg} / \mathrm{ha})^{2}$} \\
\hline & \multicolumn{2}{|c|}{$1985-86$ yield at } & \multicolumn{2}{|c|}{$1986-87$ yield at } \\
\hline & Isabela & Mayagüez & Isabela & Mayagüez \\
\hline \multicolumn{5}{|l|}{ D. alata } \\
\hline Leon Globe & 10.0 & 3.7 & 2.0 & 11.2 \\
\hline Forastero & 9.6 & 6.3 & 4.4 & 12.8 \\
\hline Florido & 10.8 & 6.1 & 13.2 & 13.2 \\
\hline Binugas & 23.1 & 8.4 & 17.4 & 13.5 \\
\hline Moresby & 17.7 & 2.9 & 19.1 & 3.6 \\
\hline Purmay & 19.2 & 1.2 & 7.7 & 5.0 \\
\hline Gerelos & 13.9 & 2.8 & 21.4 & 7.5 \\
\hline Kinabayo & 17.2 & 10.3 & 17.9 & 22.7 \\
\hline Kabusah & 21.1 & 2.1 & 17.1 & 17.6 \\
\hline Gunung & 41.2 & 10.0 & 32.7 & 25.0 \\
\hline \multicolumn{5}{|l|}{ D. esculenta } \\
\hline Kombi & 12.5 & 1.3 & 5.6 & 5.8 \\
\hline Seti & 11.4 & 3.9 & 8.4 & 6.7 \\
\hline Muni & 17.4 & 3.6 & 8.5 & 9.4 \\
\hline Doli & 21.6 & 4.8 & 11.9 & 21.0 \\
\hline Beti & 20.2 & 1.8 & 12.9 & 5.1 \\
\hline D. bulbifera & 25.3 & 10.9 & 12.1 & 6.4 \\
\hline D. rotundata "Negro" & 17.2 & 2.3 & 3.1 & 9.1 \\
\hline D. trifida"Mina" & 5.8 & 1.1 & 7.9 & 1.9 \\
\hline FLSD .05 & 8.7 & 4.0 & 5.0 & 9.6 \\
\hline .01 & 13.1 & 9.8 & 7.5 & 14.4 \\
\hline
\end{tabular}

\footnotetext{
${ }^{1}$ Means based on four 3-row plots for each cultivar.
} 
covered with blackspot lesions. On the basis of low severity and variation among the cultivars, mosaic and anthracnose data from 1986-87 and 198586 , respectively, and blackspot data are not presented. Blackspot was found primarily on $D$. esculenta cultivars in 1985-86.

To calculate yields, we harvested yams from the plot's center row after eliminating terminal plants at each end. Tubers were weighed; yields were calculated on a per hectare basis. Data were analyzed statistically for variance and means were separated: Fischer's Least Significant Difference (FLSD), with a confidence level of $\mathrm{P}<0.05$ or $\mathrm{P}<0.01$.

\section{RESULTS AND DISCUSSION}

Yam cultivars showed significantly different tuber yields at both Isabela and Mayagüez both seasons (table 1). Yields were higher at Isabela than at Mayagüez. At Isabela, Gunung was the highest yielding cultivar, but at Mayagüez it was less noteworthy. At that location it failed to outyield Kinabayo and Bulbifera in 1985-86, and Kinabayo, Kabusah, and Doli in 1986-87 (table 1). Among D. esculenta cultivars, Doli yielded highest, exceeding $20,000 \mathrm{~kg} / \mathrm{ha}$ (9.0 tons/acre) in two instances.

Diseases significantly constrained yam yields. $D$. trifida cultivar Mina showed the greatest effect of mosaic. This cultivar showed the greatest severity of virus and the lowest tuber yields (table 1 and 2). anthracnose scores in D. alata were correlated to tuber yields $\left(r=-0.81^{* * *)}\right)$. At both Isabela and Mayagüez, Gunung, Kabusah, and Kinabayo were more resistant to anthracnose and produced higher yields than most other cultivars tested. The ranking of cultivar susceptibility to anthracnose was similar in Isabela and Mayagüez; however, severity was generally greater at Isabela (table 3). In the more resistant cultivars, disease increases were primarily linear over time, whereas the very susceptible cultivars, such as Leon Globe, Forastero and Florido, showed exponential increase of anthracnose over time (table 4).

Virus and anthracnose are major limitations to yam production in western Puerto Rico. Anthracnose susceptibility varies among $D$. alata cultivars. Greater use of Gunung, Kabusah, and Kinabayo, which show considerable resistance to anthracnose, would be helpful in the control of this disease. Even when anthracnose is absent, these cultivars have higher yield potential than Florido, the most common $D$. alata currently cultivated in Puerto Rico. Studies on the acceptance of these yams should be expanded.

Dioscorea alata germplasm with superior resistance to anthracnose originated among introductions from the Phillipines and Indonesia. Greater search in the humid tropical areas of India, southeast Asia, and the previously noted island nations might reveal superior new sources of anthracnose resistance having useful adaptability to Puerto Rico. 
TABLE 2.-Mosaic severity ratings of 18 tropical yam (Dioscorea spp.) cultivars at. Isabela, Puerto Rico during the 1985-86 growing season

\begin{tabular}{lrr}
\hline \multicolumn{1}{c}{ Species and cultivar } & Mosaic severity" $^{2}$ & Resistance $^{2}$ \\
\hline D. alata & & MR \\
Leon Globe & 1.3 & MR \\
Forastero & 1.5 & $\mathrm{R}$ \\
Florido & 1.0 & $\mathrm{MR}$ \\
Binugas & 1.5 & $\mathrm{R}$ \\
Moresby & 1.0 & $\mathrm{MR}$ \\
Purmay & 1.5 & $\mathrm{R}$ \\
Gemelos & 1.0 & $\mathrm{R}$ \\
Kinabayo & 1.0 & $\mathrm{MR}$ \\
Kabusah & 1.3 & $\mathrm{MR}$ \\
Gunung & 1.5 & $\mathrm{~S}$ \\
D. eseulenta Kombi & 3.5 & $\mathrm{~S}$ \\
Seti & 3.0 & $\mathrm{~S}$ \\
Muni & 2.5 & $\mathrm{~S}$ \\
Doli & 3.3 & $\mathrm{~S}$ \\
Beti & 2.8 & $\mathrm{~S}$ \\
D. bulbifera "Bulbifera" & 2.5 & $\mathrm{~S}$ \\
D. rotundata "Guinea Negro" & 2.8 & $\mathrm{VS}$ \\
D. trifida "Mina" & 4.8 & \\
\multicolumn{1}{c}{ FLSD .01 } & 1.0 & \\
\hline
\end{tabular}

'Means from 4 ratings of each cultivar using a 0 to 5 scale, where, $0=$ no apparent mosaic and $5=$ maximum expression of mosaic.

${ }^{2}$ Resistance ratings were: $R=$ appears resistant; $M R=$ appears moderately resistant; $S=$ susceptible; and VS = very susceptible to mosaic.

TABLE 3.-Yam anthracnose (Colletotrichum gloeosporioides Penz.) severity (\% foliar necrosis), and resistance rankings for Dioscorea alata cultivars grown in Isabela and Mayagüez, Puerto Rico, during November 1986

\begin{tabular}{lcccc}
\hline & \multicolumn{3}{c}{ Anthracnose severity, at location } \\
\cline { 2 - 5 } & \multicolumn{2}{c}{ Isabela } & \multicolumn{2}{c}{ Mayaguiez } \\
\cline { 2 - 5 } Cultivar & $\begin{array}{c}\% \\
\text { Necrosis }\end{array}$ & Ranking & Necrosis & Ranking \\
\hline Leon Globe & 100 & 10 & 71 & 10 \\
Forastero & 97 & 9 & 53 & 8 \\
Florido & 83 & 8 & 30 & 6 \\
Binugas & 68 & 7 & 57 & 9 \\
Moresby & 62 & 6 & 38 & 7 \\
Purmay & 45 & 5 & 26 & 5 \\
Gemelos & 42 & 4 & 20 & 2 \\
Kinabayo & 40 & 3 & 13 & 3 \\
Kabusah & 33 & 2 & 20 & 4 \\
Gunung & 15 & 1 & 2 & 1 \\
\multicolumn{1}{c}{ FLSD .01 } & 17 & & 13 & \\
\hline
\end{tabular}

'Means based on four observations for each cultivar. 
TABLE 4.-Yam anthracnose development in three anthracnose susceptible cultivars compared to three resistant cultivars of $10 \mathrm{D}$. alata entries evaluated in Isabela and Mayagüez, Puerto Rico

\begin{tabular}{lrrrrr}
\hline & \multicolumn{5}{c}{ Yam anthracnose (\% foliar necrosis) } \\
\cline { 2 - 6 } Cultivar & July & August & September & October & November \\
\hline & & \multicolumn{5}{c}{ Isabela } \\
Leon Globe & 15 & 42 & 81 & 100 & 100 \\
Forastero & 13 & 40 & 80 & 92 & 97 \\
Florido & 7 & 15 & 35 & 65 & 83 \\
Gemelos & 15 & 20 & 27 & 33 & 42 \\
Kabusah & 8 & 12 & 15 & 21 & 31 \\
Gunung & 0 & 2 & 4 & 8 & 15 \\
$\quad$ FLSD .01 & 7 & 13 & 11 & 14 & 15 \\
& & & Mayagüez & & \\
Leon Globe & 18 & 7 & 60 & 64 & 71 \\
Forastero & 12 & 25 & 45 & 48 & 53 \\
Florida & 3 & 7 & 14 & 20 & 30 \\
Gemelos & 2 & 4 & 6 & 8 & 10 \\
Kabusah & 2 & 6 & 11 & 14 & 20 \\
Gunung & 0 & 0 & 0 & 1 & 2 \\
$\quad$ FLSD .01 & 5 & 6 & 8 & 9 & 12 \\
\hline
\end{tabular}

${ }^{1}$ Means based on 4 observations.

Binugas, a variety previously reported as anthracnose resistant in Puerto Rico (5), was susceptible in one of our trials. Gemelos showed resistant and susceptible reactions at Mayagüez and Isabela (tables 3 and 4). Variable cultivar reactions suggest that pathogenic races, and differential environmental effects, influence yam anthracnose development in Puerto Rico. Anthracnose races are described in several field crops $(1,6)$. Determination of yam anthracnose races could be useful in the development of effective disease control measures, especially plant resistance.

Besides evaluating pathogen variability, we could determine thresholds of anthracnose meriting chemical control. Control studies should also focus on proper combinations of existing strategies for anthracnose control. These include seed treatment, crop rotation, tillage, intercropping, sanitation, foliar fungicide, and use of resistant cultivars. Proper integration of existing control measures could permit expanded use of D. alata in Puerto Rico and the Caribbean, even though single control strategies might be unsuccessful.

\section{LITERATURE CITED}

1. Chaves, G., 1980. Bean anthracnose: pages 37-55 in Bean Production Problems: Diseases, Insects, Soil and Climatic Limitation to Phaseolus vulgaris. CIAT, Cali, Colombia.

2. Martin, F. W., 1974. Tropical yams and their potential. I. Dioscorea esculenta. USDA Agric. Handbook No. 451. 
3. - and H. Delpin, 1978. New superior varieties of Dioscorea alata, the Asian greater yam. J. Agric. Univ. P. R. 62 (1): 64-75.

4. - - - 1979. Selected varieties of Dioscorea esculenta, a yam for the hot humid tropics. J. Agric. Univ. P. R. 63 (2): 236-49.

5. Mignueci, J. S., M. Cordero and H. Cibes-Viadé, 1985. Diseases, insects, nematodes, and nutritional deficiencies of yams. Bull. Agric. Exp. Stn. \& Agric. Ext. Serv.

6. Nakamura, K., 1982. Physiological races of Colletotrichum graminicola (Ces.) Wils. on Sorghum bicolor. Ph.D. Thesis, Univ. Est. Paulista, Jaboticabal, Brazil. 